\title{
Counseling as a science or educational practice in multicultural philosophy dimension (A synthesize and counselor perception about counseling profession )
}

\author{
Zulfikar $^{1^{*}}$, Alfaiz $^{1}$, Ahmad Zaini ${ }^{1}$, Septya Suarja ${ }^{1}$, Nofrita $^{2}$, \& Rici Kardo ${ }^{1}$ \\ ${ }^{1}$ STKIP PGRI Sumatera Barat, ${ }^{2}$ Universitas Langlang Buana \\ *Corresponding author, e-mail: zulfikar@stkip-pgri-sumbar.ac.id
}

\begin{abstract}
Counseling has been such a trend in 21 century, as a science that studied a human in psychology perspective. However, it appear with progressive touch, has affect in human mindset in every life that undertake. In 21 century development, many opinion and argumentation about counseling has an uniqueness in philosophy multicultural perspective that counseling has linkage with cultural and philosophy values in human it self, that make a new paradigm has been raise to the surface, such indigineous counseling and multicultural counseling perspective. Regardless with that paradigm, we can t deny that basically all of science was from a human philosophy about their life with purpose to make understand and handle their life with solving a problems. But it is not all of cultural and philosophy values can be a such formulation to solve a problems, and if it can be transform to such formulation as a science, there are a procedure and criteria to be needed. Also if a counseling as a philosophy or science and also practical intervention, how to implemented in real life with a multicultural and multivalues in philosophy of life. In this article, will describe more further such a synthesize that counseling can be a science or practical science in educational multicultural philosophy paradigm and a result found that 27 (45\%) counselor perception about counseling profession that as educational practice.
\end{abstract}

Keywords: Counseling, Science, Practical, Education and Multicultural Philosophy.

How to Cite: Zulfikar, Z., Alfaiz, A., Zaini, A., Suarja, S., Nofrita, N., \& Kardo, R. (2019). Counseling as a science or educational practice in multicultural philosophy dimension (A synthesize and counselor perception about counseling profession). International Journal of Research in Counseling and Education, 3 (1): pp. 1-7, https://doi.org/10.24036/0049za0002

\section{Introduction}

Guidance and counseling as a practical discipline based on the methodology of psychology that has become one of the strengths in changing the face of education. In the 21st century, counseling becomes a practical intervention that is not only to help understand and overcome human problems through the psychology paradigm, but also from a philosophical and cultural point of view. Because every culture has its own philosophy of life, and every philosophy applies in human life, as a context of self-development of the axiology of understanding its life, counseling also has it, the axiology that is useful for clients is that counseling helps clients find themselves like to help the client to be what they must be) to be that the counselor guides and directs his philosophy of life through to help the client to find it self, to help the client to prepare it self, and to help the client to change it self (Alfaiz, Nofrita \& Dharmayanti: 2018; Naisaban: 2004).

To help direct and provide a reflection of thought and help to redefine the client's thought process, the counselor certainly does not quite understand the philosophical concepts of client culture, but the counselor must be able to transform that understanding with his philosophical logic capabilities to provide a new understanding in helping clients. Therefore, counseling science is tied to the dimensions of philosophy and culture. 
A challenge, of course, for the counseling profession in the present, which is entering the era of globalization in education. In terms of economics, Indonesia has participated in the ASEAN Economic Comunity (AEC), a community that facilitates free markets in order to develop the ASEAN economy and education in the ASEAN region (Southeast Asia), which demands competitiveness and balanced collaboration in the 21st century (Ministry of Education and Culture, 2010 ; Pelkmans, nd; "The ASEAN Economic Community and the ASEAN Investment Framework", nd; Wicaksono 2007; Chongvilaivan 2016).

In this socio-economic and educational condition, it cannot be denied that there will be acculturation and globalization of culture in Indonesia. Therefore counseling as a practical science which is a helping profession, has a wider area to explore and also becomes a challenge for counseling for itself to how to apply it in every counseling service for clients and counselors must be able to understand not all cultures can applied scientifically even though the community adheres to this culture.

Therefore, this article discusses, counseling in philosophical and cultural perspectives as well as how counseling practices philosophical and cultural approaches to practice in education and counseling conditions in Indonesia in the present and the general perception of counselors about it.

\section{Method}

This article was a qualitative research that study about many reference of manuscript and analysis through deep radical thinking and implemented to real fact in counseling practice of counselor and we combine with quantitative study through questionaire to ask about how a perception of counselor about philosophy of counseling as science or educational practice in multicultural dimension. A subject taken in this research with purposive sampling and it was counselor in 4 senior high school in center of Padang.

\section{Results and Discussion}

Judging from the word philosophy of science, consists of two words, namely philosophy and science. Philosophy and science are two interrelated words, both substantially and historically because the birth of science is inseparable from the role of philosophy. Instead the development of science strengthens the existence of philosophy. The position of philosophy as the parent of science, has a very difficult formulation process and requires deep understanding, because the value of philosophy can only be manifested by an authentic philosopher.

Philosophy is also called existential science, meaning that it is closely related to our daily lives. Even philosophy is the basis for the driving force of life, both as an individual or personal being or as a collective being in society. For that we need to understand the meaning of philosophy. The word philosophy or philosophy in Indonesian is an absorption word from Arabic, which is also taken from Greek. This word is a compound word and comes from the words philia (friendship, love etc.) and sophia ("wisdom"). If the two words are united in a new meaning (in the word philosophy) then the etymology of philosophy means love for wisdom (Hanurawan, 2012: 3). Parallel to the word philosophy, the word philosophy is also known in Indonesia in its broad meaning and is often used by all circles. Thus, it can be drawn the notion that philosophy is love for science or truth, likes wisdom and wisdom. So people who are philosophical are people who love truth, knowledge, wisdom and wisdom (Jalaluddin and Abdullah Idi, 2014: 1).

Whereas knowledge if seen in the Big Indonesian Dictionary is knowledge about a field that is compiled systematically according to certain methods that can be used to explain certain symptoms in that field. After knowing what understanding and meaning is philosophy and what science is, then an understanding of the philosophy of science will not be too difficult. This does not mean that in interpreting the philosophy of science only combines the two meanings, because as a term, the philosophy of science has experienced the development of understanding and the experts have provided a varied understanding, but understanding of the meaning of philosophy and the meaning of science will be very helpful in understanding understanding and meaning of philosophy of science (Philosophy of science).

Basically the philosophy of science is a philosophical study of matters relating to science, in other words the philosophy of science is an attempt to study and deepen the science (Science / Science), both its substance characteristics, its acquisition, or the benefits of knowledge for human life. The study is inseparable from the basic philosophical references included in the fields of ontology, epistemology and axiology with various developments and deepening carried out by experts. Referring to the understanding of the philosophy of psychology (F. Hanurawan 2012: 36) which determines that the activities of philosophical reflection in an effort to solve the problems that arise around the nature of science, the development of 
science, and the application of psychology. So the philosophy of science is the same activity as the philosophy of psychology.Top of Form

\section{Bottom of Form}

As cited by A. Susanto (2011) the experts formulated the philosophy of science as follows:

According to Berry Philosophy of Science is a study of internal logic and scientific theory and the relationships between experiment and theory, namely the scientific method. For Berry, the philosophy of science is the science used to examine the logic, scientific theories and their implementation efforts to produce a scientific method or theory.

May Brodbeck, the philosophy of science is a neutral analyst that is ethically and lazily, depicting and explaining the foundations of science according to Brodbck, science must be able to analyze, explore, study and even describe something in a neutral, ethical and philosophical manner so that science can used correctly and relevant.

Lewis White philosophy of science or philosophy of science is the science that studies and evaluates methods of scientific thought and tries to find and the importance of scientific efforts as a whole. Furthermore Lewis explained that the philosophy of science is the science that questions and assesses the methods of scientific thought and tries to establish the value and importance of scientific effort as a whole.

A. Cornelius Benjamin, argued that the philosophy of science is a systematic study of the nature and nature of science, especially with regard to its method, its concept, its position in the general schema of intellectual discipline. Benyamin looks more at the nature and nature of science in terms of methods, concepts, and position in scientific disciplines.

Robert Ackermann's philosophy of science is a critical assessment of current scientific opinions in comparison to past opinions that have been proven or in the framework of measures developed from such opinions, but the philosophy of science is clearly not a branch knowledge that is free from actual scientific practice.

Furthermore Jujun Suriasumantri (2005: 33-34) views philosophy of science as part of epistemology (philosophy of knowledge) to answer three groups of questions about the nature of science as follows:

The first group of questions includes the following; What do you study? What is the ultimate form of the object? What is the relationship between the object and the human capture power? The second group of questions: What is the process that allows the acquisition of knowledge in the form of knowledge? How does this work? What things must be considered so that we get the right knowledge? What is meant by truth? Etc.

And finally, the third group of questions: For what knowledge is knowledge? What is the connection between how to use knowledge and moral principles? How is the determination of objects examined based on moral choices? Etc.

The first group of questions is an ontological science review. Whereas the second group questions are epistemological science reviews. And third group questions as an axiological review of science. Based on some opinions of the experts above it can be concluded that the philosophy of science is a philosophical study that wants to answer questions about the nature of science, both in terms of its ontological, epistemological and axiological aspects. In other words, the philosophy of science is part of epistemology (philosophy of knowledge) that specifically examines the nature of science.

\section{Guidance and Counseling as Science}

Similarly, the philosophy of science which consists of two words, the science of Guidance and Counseling or BK also consists of two words, namely science and counseling. Speaking of what knowledge we have discussed in the Big Indonesian Dictionary that science is knowledge about a field that is arranged systematically according to certain methods that can be used to explain certain symptoms in that field. Whereas according to Stefanus (2013) science is a collection of knowledge that is compiled consistently and the truth has been tested empirically. It should be realized that the proof in science is not absolute. Thus science is a combination of several knowledge that are arranged consistently and systematically that can be tested for truth so that it can be used to explain certain symptoms.

While Guidance and Counseling also consists of two words, guidance and counseling. Guidance is a process of individual assistance so that he helps himself so that his welfare is achieved (Lasan, 2014: 30). Counseling comes from English, the word to counsel, which means advising. Counseling is a process of giving assistance carried out by an expert (called a counselor / counselor) to individuals who experience a problem 
(called counselee) which leads to overcoming the problems faced by the client. Thus guidance and counseling is a process of giving assistance from someone who is an expert to others to resolve problems and establish them.

Episthemology slice Guidance and Counseling in the framework of scientific diversity. Lasan (2015) in a journal with the title identifies the nature of Guidance and Counseling, emphasizing that Guidance and Counseling has not become a science or is in the process of becoming a science. In terms of science, the thesis that the process of being a science means that Guidance and Counseling at this time is not or has not become pure science. Thus Guidance and Counseling are more precisely applied sciences. Guidance and counseling apply theories from several pure sciences including philosophy, anthropology, sociology and psychology.

Guidance and Counseling is a scientific field that relies on other fields of science. This is further explained by Gibson \& Mitchell (2008: 46-47) When discussing the roots and emergence of counseling as a helping profession, we must also note the foundation for counseling as a scientific discipline. Most of these foundations are derived from scientific disciplines of psychology. The contribution of psychology includes the theory and process of counseling, standard assessment, individual and group counseling techniques, and career development and decision-making theory.

The area of specialization in psychology has a further contribution to the building of knowledge on which counselors work. Primarily, this building is formed by educational psychology and its studies of learning theory, human growth and its implications for the scope of education. Then, social psychology helps us understand the influences of social situations for individuals, including environmental influences for certain behaviors. While ecological psychology highlights environmental studies and how individuals perceive, form and influence their environment. Finally, developmental psychology helps us understand why and how individuals grow and change throughout their lives.

It must be admitted that our strongest disciplinary bond is in the field of psychology, but we also have to recognize the important contribution of other sciences to the counseling profession. For example, for example, sociology contributes to the understanding of human groups and their influence on social institutions and change. Anthropology provides counselors with an understanding of human cultures, which in turn provides signs for how to behave and view its members. Biology helps us understand the human organism and its uniqueness. Whereas the health profession makes us aware of the importance of life welfare and prevention of diseases, deviations and disorders both mental and physical.

\section{Counseling; Philosophy of Science and Educational Practice in Indonesia}

Humans have the curious nature of everything; something that is known to man is called knowledge. Knowledge is divided into 4 (four), namely sensory knowledge, scientific knowledge, philosophical knowledge, religious knowledge. The term "knowledge" is not the same as "science". A human knowledge can come from his experience or can also come from other people while knowledge is knowledge that has certain objects, methods, and systematic as well as knowledge is also universal (I Gusti Bagus Rai Utama, 2013: 72).

Progressing and developing knowledge does not mean that all questions can be answered, therefore various unanswered questions become part of philosophical studies. Harry Hamersma (1990: 13) stated that philosophy came before and after the knowledge of the question question Harry Hamersma (1990: 9) stated that the questions posed by science (specifically) may also never be answered by philosophy.

Philosophy does not investigate any aspect of reality, but what attracts human attention, this assumption is reinforced that since the 20th century philosophy is still busy with the same problems as 2,500 years ago which actually proves that philosophy remains loyal to "the method itself". The difference between philosophy and other sciences is science. Science is methodical, systematic, and coherent knowledge of a particular field of reality, while philosophy is methodical, systematic, and coherent knowledge of all reality.

The essence of these differences concludes that philosophy is an infinite science because it has the requirements according to science. Philosophy can also be viewed as a view of human life so that there is philosophy as a view of life or called the way of life, Weltanschauung, Wereldbeschouwing, Wereld-en levenbeschouwing that is as a direction of human activities in all fields of life and philosophy as well as science with definitions like described above (I Gusti Bagus Rai Utama, 2013: 72).

This can also be related to the meaning of a particular philosophy of science. The philosophy of a particular science is the field of philosophical study that is more specific to certain sciences, for example: Philosophy of Knowledge, Moral Philosophy, Philosophy of Art, Philosophy of Government, Philosophy of Religion, Philosophy of Education, Philosophy of Science and so on (I Gusti Bagus Rai Utama, 2013: 74) The 
same is true with the science of Guidance and Counseling having a philosophy which is the basic view or foundation of the construction of Guidance and Counseling science itself or as a basis for direction in all activities (activities) Guidance and Counseling knowledge itself.

The philosophy of the science of Guidance and Counseling is basically autonomy in BK's scientific philosophy which discusses the development of behaviors that are in accordance with developmental tasks (Lasan, 2014). The cornerstone of philosophy will underlie the objectives of Guidance and Counseling in accordance with human nature, then every guidance and counseling effort is expected not to deviate from the nature of human beings themselves.

Philosophy seeks to guide, direct all counseling practices because counseling practices that do not have a philosophical foundation will experience a meaningless vacuum. A counselor in interacting with his client must be able to see and treat his client as a whole human being with various dimensions. This is in accordance with the foundation of philosophy adopted, one of which is philosophy of humanism. Humanism as a philosophy of counseling guidance and educational practice is understood to have many diverse elements (J. T. Hansen, 2006). The principle that brings together diverse elements is the idea that humans cannot be reduced to other phenomena (L. Davidson, 2000). In other words, humans can only be understood as whole beings. So counseling as an applicative science of human philosophy itself to understand humans in terms of psychology, namely psychological, psychological formation is applied in the process of education and learning.

It can be concluded that the philosophical foundation provides thoughts about the nature and purpose of human life to discover the nature of human beings as a whole considering that counseling guidance will always be related to humans as their object. Thought about human nature, Objectives and Tasks Human life is expected to have positive implications for the implementation of guidance and counseling, namely the counselor will have accurate guidelines in carrying out guidance services, counseling is carried out and directed in accordance with humanity's human values.

John J. Pietrofesa et.al. (1980: 30) then expressed James Cribbin's opinion about philosophical principles in the guidance as follows:

Guidance should be based on recognition of the individual's (client's) glory and dignity and of his rights to get help.

Guidance is a continuous educational process. The meaning of guidance is an integral part of education.

Guidance must respect the rights of every client who asks for help or service.

Guidance is not a special group prerogative of the mental health profession. Guidance is carried out through collaboration, each of which works based on their own expertise or competence.

The focus of guidance is to help individuals realize their potential.

Guidance is an element of education that is individualized, personalized, and socialized.

Based on this, a survey was conducted on school counselor perceptions of how counseling is in its application, whether as a theoretical or more theoretical science, namely practical knowledge from psychology in education to understand student culture in education and teaching.

In a figure below can be seen that the counselor's perception of the counseling profession in the counseling process seen from the philosophy of cultural dimensions of serving clients obtained as many as 27 people from 60 respondents stated that counseling is practical knowledge in education, and 18 respondents stated that counseling was scientific and also as practical knowledge in education.

Table 1. Counselor Perception of Counseling Profession

\begin{tabular}{ccc}
\hline Counseling As & Frequency & \% \\
\hline Science & 15 & 25,00 \\
\hline Educational Practice & 27 & 45,00 \\
\hline Both are True & 18 & 30,00 \\
\hline & 60 & 100 \\
\hline
\end{tabular}




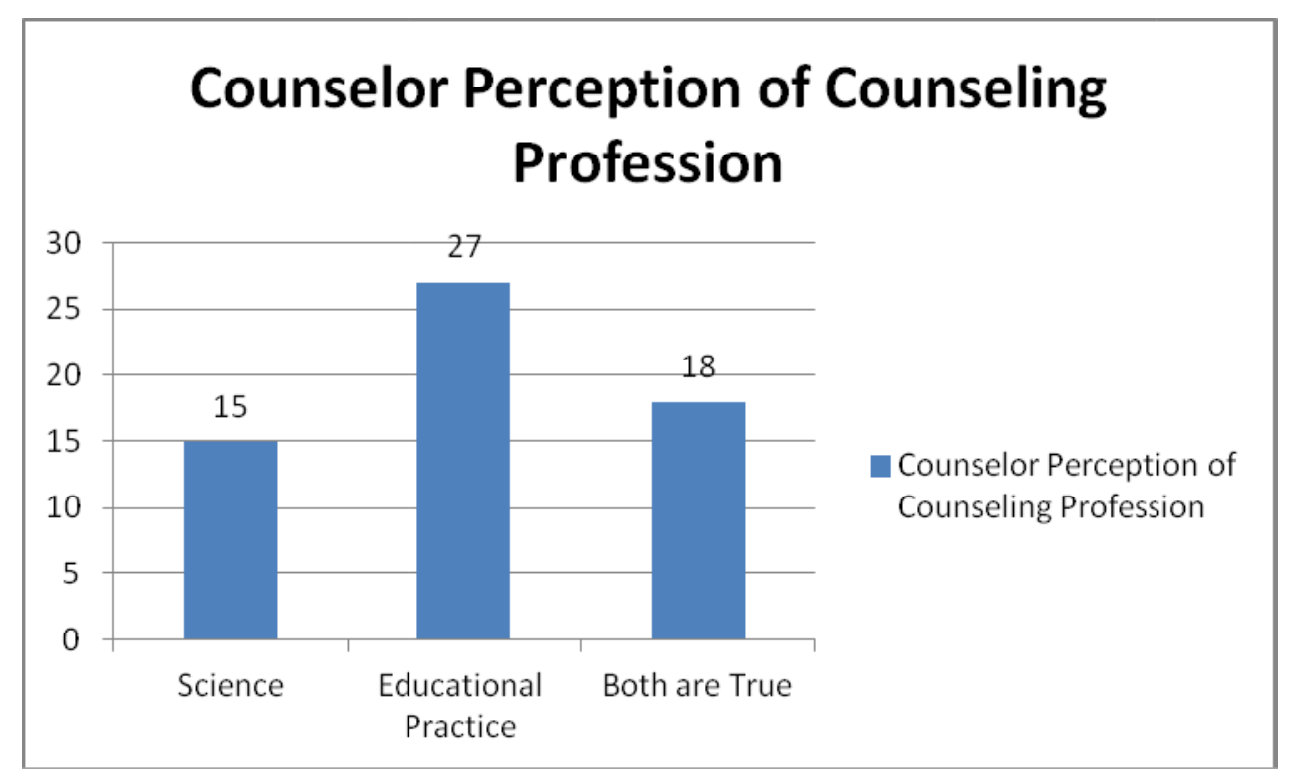

Figure 1. A Graphic Frequency of Counselor Perception

\section{Conclusion}

The philosophy of science is a philosophical study that wants to answer questions about the nature of science, both in terms of its ontological, epistemological and axiological aspects. In other words, the philosophy of science is part of epistemology (philosophy of knowledge) that specifically examines the nature of science.

Guidance and Counseling is a process of giving assistance from someone who is an expert to others to resolve problems and establish them. Guidance and Counseling is a scientific field that relies on other fields of science. Guidance and counseling apply theories from several pure sciences including philosophy, anthropology, sociology and psychology. Thus Guidance and Counseling are more precisely applied sciences.

Guidance and Counseling has a philosophy that is the basic view or foundation of the construction of Guidance and Counseling science itself or as a basis for direction in all activities (activities) Guidance and Counseling activities themselves. The cornerstone of philosophy will underlie the objectives of Guidance and Counseling in accordance with human nature, then every guidance and counseling effort is expected not to deviate from the nature of human beings themselves. A counselor in interacting with his client must be able to see and treat his client as a whole human being with various dimensions. Philosophy seeks to guide, direct all counseling practices because counseling practices that do not have a philosophical foundation will experience a meaningless vacuum.

\section{Acknowledgment}

Finishing this article cannot be separated from any support, sharing and solid collaboration and also high expectation from all of authors in search a study document also with deep analysis and synthesis that result an idea that establish in this article. Authors also thanks to International Journal of Research in Counseling and Education (IJRiCE) and Editor In Chief Mr. Zadrian Ardi, M.Pd, Kons that has been give an opportunity for contribution in publication and also contribution for development and understanding about philosophy of counseling in Indonesia in theoretical perspective and also qualitative and quantitative research perspective for counseling profession. 


\section{References}

Alfaiz. (2017). Sufism Approached in School Counseling Service: An Analysis of Perspective Spiritual Counseling. Jurnal Schoulid: Indonesian Journal of School Counseling. Vol. 2, No. 1. https://doi.org/10.23916/008621423-00-0. http://journal.konselor.or.id/index.php/schoulid/article/view/42

Alfaiz. A, Rafiola. R.H, Hariko. R, \& Zulfikar. Z. (2017). Condition and Shaping of Student Personality in Educational Process Through Transpersonal Psychology Perspective. Proceedings of The 3rd International Conference on Education and Training (ICET 2017). https://www.atlantispress.com/proceedings/icet-17/25883491. https://doi.org/10.2991/icet-17.2017.1

Alfaiz, Zulfikar \& Yulia, D. (2017). Efikasi Diri sebagai Faktor Prediksi Kesiapan Mahasiswa dalam Mengerjakan Tugas Kuliah. IImu Pendidikan: Jurnal Kajian Teori dan Praktik Kependidikan. 2(2). pp. 119-124. http://journal2.um.ac.id/index.php/iktpk/article/view/2546.

Alfaiz, A. (2018). Guidance and Counseling Profession: a Philosophy and Professional Challenges In The Future. Couns-Edu: International Journal of Counseling and Education, 3(1): pp. 44-47. DOI: https://doi.org/10.23916/0020180313420. http://journal.konselor.or.id/index.php/counsedu/article/view/134.

Alfaiz, D., \& Yandri, H. (2015). Self Concept and Self Efficacy As A Ground Points in A Social Activities (An Analysis of Psychology Perspective: A Social Cognitive Theory). Jurnal Pelangi, 7(2), 45-52. http://ejournal.stkip-pgri-sumbar.ac.id/index.php/pelangi/article/view/203. DOI: https://doi.org/10.22202/ip.2015.v7i2.203.

Alfaiz. (2014). Pembelajaran Afektif Merupakan Salah Satu Strategi Dalam Pembentukkan Karakter Peserta Didik. Jurnal Pelangi, Vol. 7, No. 1, 94-105. http://ejournal.stkip-pgrisumbar.ac.id/index.php/pelangi/article/view/152. DOI: https://doi.org/10.22202/jp.2014.v7i1.152.

Chongvilaivan, Aekapol. (2016). "Does Outsourcing Enhance Skill Premiums in ASEAN?". In ASEAN Economic Community, 217-29. Palgrave Macmillan US. doi:10.1057/9781137535085_11.

Davidson, L. (2000). Philosophical foundations of humanistic psychology. Humanistic Psy-chologist, 28, 7 31.

Faiz, A., Dharmayanti, A., \& Nofrita, N. (2018). Etika Bimbingan dan Konseling dalam Pendekatan Filsafat Ilmu. Indonesian Journal of Educational Counseling, 2(1), 1-12. https://doi.org/10.30653/001.201821.26. http://ijec.ejournal.id/index.php/counseling/article/view/26

Gibson, Robert L. \& Mitchell, Marianne H. (2008). Introduction to Counseling and Guidence. Alih bahasa Yudi Santoso: Bimbingan dan Konseling. Yogyakarta: Pustaka Pelajar.

Hanurawan Fatah. (2012). Filsafat Ilmu Psikologi. Malang: Fakultas P. Psikologi. Universitas negeri Malang

Hamersma, Harry. (1990). Tokoh-Tokoh Filsafat Barat Modern. Jakarta: Gramedia Pustaka Utama.

Hansen, J. T. (2006). Humanism as ideological rebellion: Deconstructing the dualisms of contemporary mental health culture. Journal of Humanistic Counseling, Education and Development, 45, 3-16.

Jalaluddin dan Abdullah Idi. (2014). Filsafat Pendidikan. Jakarta: Rajawali Pers.

Jujun S. Suriasumantri. (2005). Filsafat IImu : Sebuah Pengantar Populer: Jakarta : Sinar Harapan.

Lasan, B.B. (2014). Konselor Sekolah: Tinjauan dan Upaya Profesionalisasi. Malang: Elang Ma.

Lasan, B.B. (2015). Mengidentifikasi Keilmuan Bimbingan dan Konseling. Dalam Jurnal Bimbingan Konseling, Vol, 28, Nomor 2: 83-89.

Lengeveld. Tt. (1955). Menuju ke Pemikiran Filsafat, terj. G.J. Claessen, Jakarta: PT Pembangunan.

Pietrofesa, J.J. et.al. (1980). Guidance An Introduction. Chicago: Rand McNally College Publishing Company.

Supriyanto, Stefanus. (2013). Filsafat IImu, Jakarta: Prestasi Pustaka.

Susanto A. (2011). Filsafat Ilmu, Jakarta: Bumi Aksara.

Utama, I Gusti Bagus Rai. (2013). Filsafat IImu dan Logika. Bandung: Universitas Dhyana Pura

Wicaksono, Agung. (2007). "Think ASEAN! : Rethinking Marketing toward ASEAN Community 2015". Asean Economic Bulletin 24 (2). Institute of Southeast Asian Studies: 278-80. doi:10.1355/ae24-2h. 